\title{
Kajian Kualitas Air Tanah Dampak Intrusi di Sebagian Pesisir Kabupaten Tuban
}

\author{
Erik Febriarta $^{{ }^{*}}$, M. Widyastuti ${ }^{2}$ \\ ${ }^{1}$ Magister Pengelolaan Pesisir dan Daerah Aliran Sungai, Fakultas Geografi, Universitas Gadjah Mada, Yogyakarta, Indonesia \\ ${ }^{2}$ Fakultas Geografi, Universitas Gadjah Mada, Yogyakarta, Indonesia \\ ${ }^{1}$ Palawa Karya, Yogyakarta, Indonesia
}

\section{Article Info}

Article History

Dikirim 24 April 2020

Diterima 1 Juni 2020

Terbit 29 Juli 2020

\section{Keywords:}

air tanah; intrusi; kualitas air; pesisir

groundwater; intrusion; water quality; coastal

\begin{abstract}
Abstrak
Wilayah Kabupaten Tuban bagian utara berbatasan langsung dengan Laut Jawa dengan pembangunan terpusat pada daerah pesisir. Salah satu isu permasalahan yang timbul dari pertumbuhan kota pesisir adalah penurunan kualitas air tanah akibat intrusi air laut. Penelitian ini bertujuan mengetahui kualitas air tanah yang terdapak intrusi air laut. Metode yang digunakan untuk mengetahui kondisi kualitas air tanah dengan analisis perbandingan dengan nilai baku mutu PermenKes RI No.32 Tahun 2017. Unsur yang dianalisis e.coli, e.coli total, nitrit (N02), nitrat (N03), bau, total zat padat terlarut (TDS), rasa, daya hantar listrik (DHL), besi (Fe), khlorida (Cl), sulfat (S04), kesadahan $(\mathrm{CaC03})$, keasaman $(\mathrm{pH})$, natrium $(\mathrm{Na})$, kalium $(\mathrm{K})$, bikarbonat $(\mathrm{HC} 03)$, karbonat (C03), kalsium (Ca). Unsur yang melebihi baku mutu antara lain ecoli yang bersumber dari limbah rumah tangga (domestik), nitrat (N03) yang bersumber dari pupuk pertanian, daya hantar litrik (DHL) bersumber dari ion garam terlarut dan kesadahan (CaC03) yang bersumber dari batuan kapur. Sedangkan metode untuk mengetahui dampak intrusi air laut adalah dengan perbandingan ion mayor yaitu $\mathrm{Mg} 2+$ dan $\mathrm{Ca} 2+$, dan $\mathrm{Cl}-$ dan HC03-. Hasil penelitian menunjukkan 11 dari 12 sampel atau 91\% terpengaruh intrusi air laut.
\end{abstract}

\footnotetext{
*E-mail :e.febriarta@gmail.com

Address : Bulaksumur, Yogyakarta, Indonesia 55281
} 


\section{PENDAHULUAN}

Air tanah merupakan bagian dari kebutuhan dasar bagi manusia dan makhluk hidup disekitar yang diperlukan untuk keberlangsungan hidup. Air tanah merupakan media yang dapat berubah dan menyerap disetiap batuan yang dilewatinya (Fetter, 2014). Air tanah mempunyai sifat melarutkan mineral yang terkandung didalam batuan yang dilewatinya (Mishra et all, 2015) Sehingga kandungan mineral yang terkandung dalam suatu akuifer sangat dipengaruhi oleh material batuan yang dilewatinya atau dapat didefinisikan sebagai tipe air tanah dari unsur kimia air (Singhal dan Gupta, 2010.). Selain dari kondisi geologi, kualitas air tanah dapat dipengaruhi oleh lokasi terhadap laut. Semakin mendekati laut karakteristik air tanah mendekati payau hingga asin. Karakteristik air tanah pesisir yang dominan payau memiliki nilai daya hantar listrik yang relatif tinggi selain dari sifat fisik mempunyai rasa asin (Febriarta et al, 2018; Hounsinou, 2020)

Air tanah di kawasan pesisir sangat dinamis, faktor yang mempengaruhi antara lain jarak terhadap laut, kedalaman air tanah, porositas batuan, dan aktivitas manusia diatasnya (Purnama, 2010). Musim juga mempengaruhi dinamika tersbut, dimana pada musim kemarau memiliki potensi intrusi air laut lebih besar dari pada musim penghujan (Hounsinou, 2020). Intrusi air laut merupakan pertistiwa masuknya air laut kedalam akuifer air tanah tawar diakibatkan oleh dorongan atau tekanan air laut dimana dapat diakibatkan oleh rongga akuifer air tanah tawar kosong (Purnama, 2010; Suharno et al, 2015). Faktor tersebut mengakibatkan secara kualitas air tanah menurun.

Penurunan kualitas air tanah memiliki dampak tidak dapat tidak dapat dikonsumsi pada jumlah tertentu atau sama sekali tidak dapat dikonsumsi oleh manusia dan mahluk hidup disekitarnya. Air tanah yang kualitasnya menurun mempunyai dampak kesehatan bagi tubuh manusia atau mahkluk hidup disekitar yang mengkonsumsi. Terbatasnya air tanah yang dapat dikonsumsi sangat dipengaruhi oleh batas kebutuhan dasar manusia atau makhluk hidup atau disebut dengan kadar baku mutu (Febriarta et al, 2018). Pentingnya informasi kualitas air tanah diperlukan sebagai cara adaptasi dalam rangka memenuhi kebutuhan hidup dan sangat mempengaruhi pola penggunaan air tanah, dimana air tanah merupakan kebutuhan dasar (Widada et al, 2018). Perubahan unsur yang dominan dari intrusi air laut dapat dilihat dari komposisi kimia air tanah diantaranya dari ion klorida (Cl) (Singhal dan Gupta, 2010; Purnama 2010; Cahyadi et al, 2017). Unsur kimia dari air ta- nah yang dominan terdampak intrusi ditunjukkan dari kandungan nilai sodium $(\mathrm{Na})$ dan klorida $(\mathrm{Cl})$ yang relatif tinggi (Suhartono et al, 2015, Cahyadi et al, 2017; Hounsinou, 2020).

Kabupaten Tuban memiliki wilayah di pesisir pantai utara Pulau Jawa. Petumbuhan permukiman berada di kawsan pesisir, dikarenakan memiliki kondisi topografi yang datar dan terdapat akses jalan utara antar provinsi. Pertumbuhan ekonomi dan pembangunan daerah mempunyai dampak perubahan ruang wilayah menjadi lahan terbangun dengan aktivitas manusia. Pola perkembangan pembangunan yang berada di sepanjang pesisir, memiliki dampak diantaranya dari sisi penggunaan air tanah adalah pengambilan air tanah yang melebihi kapasitas daya dukung dari akuifer air tanah sehingga mengakibatkan intrusi air tanah dan menurunkan kualitas air tanah. Selain penggunaan air di kawasan permukiman dan kawasan kegiatan ekonomi, pola pengarian dari kegiatan pertanian dan sawah di pesisir juga mempercepat kontaminasi atau intrusi air laut. Faktor tersebut dipengaruhi oleh pengambilan air tanah dangkal untuk kegitan pertanian dan sawah. Penurunan kualitas air tanah dapat mengakibatkan penurunan kesehatan. Berdasarkan latar belakang tersebut, maka tujuan dari penelitian ini adalah mengetahui kualitas air tanah dilihat dari unsur mayor di dalam air dan mengkaji potensi daerah yang terdampak intrusi air laut dengan perbandingan ion mayor.

\section{METODE PENELITIAN}

Lokasi pengambilan sampel air tanah berada di dataran pantai, secara administrasi berada di Kecamatan Tambakboyo dan Kecamatan Jenu. Metode pengambilan titik sampel air tanah menggunakan purposive sampling, dengan pertimbangan sampel air yang digunakan digunakan sehari-hari atau kegiatan domestik dan mewakili di kawasan permukiman. Berdasarkan pendekatan tersebut diperoleh jumlah sampel sejumlah 12 titik pengambilan. Sumber air sampel berasal dari 6 titik dari sumur bor (SB) dan 6 titik dari sumur gali (SG). Lokasi titik sampel disajikan pada Gambar 1.

\section{Analisis Nilai Daya Hantar Listrik (DHL)}

Parameter pengukuran yang dapat diuji langung dilapangan antara lain nilai Daya Hantar Listrik (DHL), bau dan rasa. Pendekatan nilai daya hantar listrik (DHL) mempunyai korelasi dengan nilai salinitas, yang disebabkan oleh ion garam terlarut (Youger, 2007; Aries et al, 2013; Hounsinou, 2020). Sehingga distribusi nilai daya hantar listrik (DHL) dapat digunakan sebagai persebaran pen- 


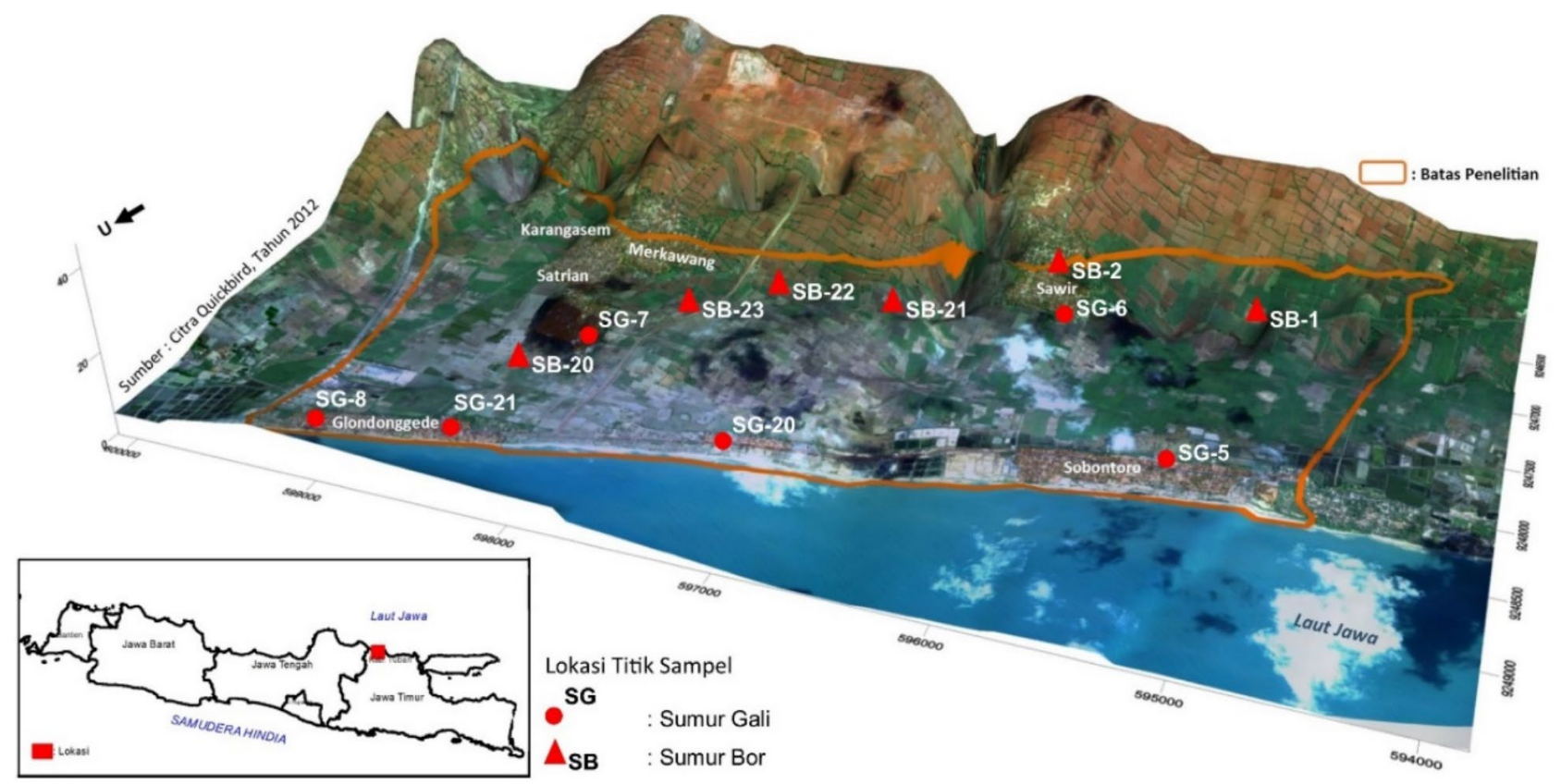

Gambar 1. Lokasi titik sampel air

garuh intrusi air laut secara keruangan (Hounsinou, 2020). Analisis salinitas adalah kadar garam terlarut dalam air dengan satuan salinitas adalah per mil (\%o). Data yang diperoleh disajikan dengan metode ektrapolasi dalam Sistem Informasi Geografis (SIG). Nilai kelas salinitas berdasarkan nilai daya hantar listrik ditunjukkan dalam Tabel 1, sebagai berikut (Suherman, 2007).

Tabel 1. Korelasi DHL terhadap salinitas

\begin{tabular}{cc}
\hline Kualitas Air & DHL $(\mu \mathrm{S} / \mathrm{cm})$ \\
\hline Tawar & $<1.500$ \\
Agak Payau & $>1.500-\leq 5.000$ \\
Payau & $>5.000-\leq 15.000$ \\
Asin & $>15.000-\leq 50.000$ \\
Brine & $>50.000$ \\
\hline
\end{tabular}

\section{Analisis Kualitas Air}

Parameter unsur uji laboratorium, dilakukan pengambilan sampel air dengan menggunakan botol sampel tertutup dan untuk sampel biologi yaitu unsur coli, diberi pendingin untuk menjaga kondisi air sampel tidak berubah sampai uji laboratorium. Waktu pengambilan sampel air musim kemarau. Setiap pengambilan titik sampel dilakukan pencatatan koordinat lokasi dengan Global Positioning System (GPS). Lokasi pengambilan titik sampel air disajikan pada Gambar 1. Penyajian data secara keruangan (spasial) titik pengambilan sampel menggunakan Sistem Informasi Geografi (SIG).

Sampel air yang digunakan untuk uji kualitas air tanah bersumber langsung dari sumur gali dan sumur bor. Parameter yang digunakan untuk men- getahui kualitas air antara lain biologi, an organik, fisik dan kimia. Satuan usur yang diuji untuk parameter kualitas air disajikan pada Tabel 2. Untuk mengetahui kadar maksimal baku mutu terhadap konsumsi manusia mengacu nilai baku mutu (kadar maskimal) dari PermenKes RI No.32 Tahun 2017, tentang standar baku mutu kesehatan lingkungan dan persyaratan kesehatan air untuk keperluan hygiene sanitasi, dan untuk nilai unsur yang tidak terdapat di pemenkes, yaitu unsur natrium $(\mathrm{Na})$, kalium $(\mathrm{K})$, bikarbonat $\left(\mathrm{HC}^{3}\right)$, magnesium $(\mathrm{Mg})$ dan kalsium $(\mathrm{Ca})$ merujuk nilai dari baku mutu Todd dan Mays (2005).

\section{Perbandingan Ion Mayor terhadap Intrusi Air Laut}

Analisis pengaruh intrusi air laut di akuifer pesisir dapat diketahui dengan pendekatan analisis perubahan air tawar menjadi air laut berdasarkan perbandingan nilai ion mayor (Youger, 2007). Analisis pengaruh intrusi air laut dapat diketahui dengan perbandingan ion Kalsium $\left(\mathrm{Ca}^{2+}\right)$ dan Magnesium $\left(\mathrm{Mg}^{2+}\right)$ dan perbandingan ion klorida $(\mathrm{Cl})$ dengan Bikarbonat $\left(\mathrm{HCO}_{3}{ }^{-}\right.$) (Aries et al, 2013). Kemudian untuk penyajian perbandingan disajikan dengan gambar scatter plot. Kriteria yang pengaruh intrusi air laut dapat dilihat pada Tabel 3, sebagai berikut (Aries et al, 2013):

\section{HASIL DAN PEMBAHASAN}

Hasil pengukuran untuk mengetahui kondisi kualitas air tanah di pesisir diperoleh dari uji laboratorium. Jumlah sampel yang diuji sejumlah 12 
Tabel 2. Unsur parameter baku mutu air

\begin{tabular}{|c|c|c|c|c|c|}
\hline & Parameter & Unsur & Baku mutu & Unit & Baku Mutu \\
\hline \multirow{2}{*}{\multicolumn{2}{|c|}{1 Biologi }} & 1 E.Coli & & $\mathrm{CFU} / 100 \mathrm{ml}$ & 0 \\
\hline & & 2 E.Coli Total & & $\mathrm{CFU} / 100 \mathrm{ml}$ & 50 \\
\hline \multirow[t]{2}{*}{2} & An Organik & 1 Nitrit $\left(\mathrm{NO}^{2}\right)$ & & $\mathrm{mg} / 1$ & 10 \\
\hline & & 2 Nitrat $\left(\mathrm{N}^{3}\right)$ & PermenKes RI & $\mathrm{mg} / 1$ & 1 \\
\hline \multirow[t]{4}{*}{3} & Fisik & $1 \mathrm{Bau}$ & No.32 Tahun & - & Tidak berbau \\
\hline & & $\begin{array}{l}2 \text { Total zat padat ter- } \\
\text { larut (TDS) }\end{array}$ & $\begin{array}{l}\text { 2017,tentang } \\
\text { standar baku }\end{array}$ & $\mathrm{mg} / 1$ & 1000 \\
\hline & & 3 Rasa & mutu kesehatan & - & Tidak berasa \\
\hline & & $\begin{array}{l}4 \text { Daya Hantar Listrik } \\
\text { (DHL) }\end{array}$ & $\begin{array}{l}\text { lingkungan dan } \\
\text { persyaratan kes- } \\
\text { ehatan air untuk }\end{array}$ & $\mu \mathrm{mhos} / \mathrm{cm}$ & 1000 \\
\hline \multirow[t]{10}{*}{4} & Kimia & 1 Besi $(\mathrm{Fe})$ & keperluan hygiene & $\mathrm{mg} / 1$ & 1 \\
\hline & & 2 Khlorida $(\mathrm{Cl})$ & sanitasi & $\mathrm{mg} / 1$ & 250 \\
\hline & & 3 Sulfat $\left(\mathrm{SO}_{4}\right)$ & & $\mathrm{mg} / 1$ & 400 \\
\hline & & 4 Kesadahan $\left(\mathrm{CaCO}_{3}\right)$ & & $\mathrm{mg} / 1$ & 500 \\
\hline & & 5 Keasaman $(\mathrm{pH})$ & & $\mathrm{mg} / 1$ & $6,5-8,5$ \\
\hline & & 6 Natrium $(\mathrm{Na})$ & & $\mathrm{mg} / 1$ & 200 \\
\hline & & 7 Kalium (K) & & $\mathrm{mg} / 1$ & 50 \\
\hline & & 8 Bikarbonat $\left(\mathrm{HCO}^{3}\right)$ & Todd dan Mays & $\mathrm{mg} / 1$ & 500 \\
\hline & & 9 Magnesium (Mg) & & $\mathrm{mg} / 1$ & 50 \\
\hline & & 10 Kalsium $(\mathrm{Ca})$ & & $\mathrm{mg} / 1$ & 100 \\
\hline
\end{tabular}

Tabel 3. Perbandingan ion terhadap intrusi air laut

\begin{tabular}{ccl}
\hline No. Perbandingan Ion & \\
\hline 1 & $\mathrm{Mg}^{2+}$ dan $\mathrm{Ca}^{2+}$ & $\mathrm{Mg}^{2+} / \mathrm{Ca}^{2+}>1 ;$ air tanah terpengaruh intrusi air laut \\
& & \\
& & \\
2 & $\mathrm{Cl}^{-}$dan $\mathrm{Cl}^{-} / \mathrm{HCO}_{3}^{-}<0.5 ;$ air tanah belum terpengaruh intrusi air laut, \\
& & 2. $\mathrm{Cl}^{-}$dan $\mathrm{HCO}_{3}^{-}$antara $0.5-6,6$ air tanah terpengaruh sedikit intrusi air laut, \\
& 3. $\mathrm{Cl}^{-}$dan $\mathrm{HCO}_{3}^{-}>6,66$ air tanah sudah terpengaruh air laut.
\end{tabular}

sampel. Nilai keakuratan pengujian Cation Anion Balance atau Charge Balance Error (CBE) hasil uji laboratorium $<8 \%$ (Tabel 4), sehingga hasil tersebut memiliki tingkat keakuratan yang tinggi dan dapat digunakan untuk analisis kualitas air. Parameter yang diuji anatara lain parameter biologi, an organik, fisik dan kimia.

Unsur dari parameter biologi terdiri dari e.coli dan e.coli total. Berdasarkan hasil uji menunjukkan seluruh sampel melebihi nilai baku mutu yaitu nilai kadar 0 untuk e.coli, sedangkan kadar baku mutu untuk e.coli total adalah kadar 50. Sampel yang bersumber dari sumur gali menunjukkan nilai yang lebih tinggi dibanding sampel sumur bor (Gambar 2). Hal ini dimungkinkan sumur gali memiliki kedalaman relatif dangkal dan mendapatkan sumber pencemar dari aliran permukaan yang masuk ke akuifer dangkal.

Unsur dari parameter an organik terdiri dari nitrit $\left(\mathrm{NO}^{2}\right)$ dan nitrat $\left(\mathrm{NO}^{3}\right)$. Berdasarkan hasil uji laboratorim diketahui kadar nitrit $\left(\mathrm{N}^{2}\right)$ seluruh sampel dibawah baku mutu, yaitu $<1$. Sumber nitrit $\left(\mathrm{NO}^{2}\right)$ dapat bersumber dari limbah kegiatan rumah tangga atau limbah domestik. Sedangkan kadar nitrat $\left(\mathrm{N}^{3}\right)$ seluruh sampel melebihi baku mutu, yaitu $>50$ (Gambar 3). Nilai nitrat $\left(\mathrm{NO}^{3}\right)$ yang tinggi dimungkinkan berasal dari limbah pertanian dimana penggunaan lahan di lokasi penelitian terdapat pertanian dan sawah (Gambar 1). Sumber dari nitrat $\left(\mathrm{N}^{3}\right)$ dapat dimungkinkan dari pupuk pertanian yang berlebihan dan masuk kedalam akuifer. Selain pencemaran pupuk, nilai nitrat $\left(\mathrm{N}^{3}\right)$ dapat menunjukkan kedekatan dengan air laut dimana konsentrasi nitrat $\left(\mathrm{N}^{3}\right)$ di pantai 0-30 $\mathrm{mg} / 1$. Berdasarkan hasil tersebut konstrasi nitrat $\left(\mathrm{N}^{3}\right)$ yang berkorelasi dengan intrusi air latu ditunjukkan dari sampel SB-1, SB-2, SB-21, SB-23, SG6, dan SG-8.

Unsur dari parameter fisik yang diuji anatra lain bau, total zat adat (TDS), rasa, dan daya hatar listrik (DHL). Berdasarkan hasil seluruh sampel uji laboratorium menunjukkan unsur tidak 


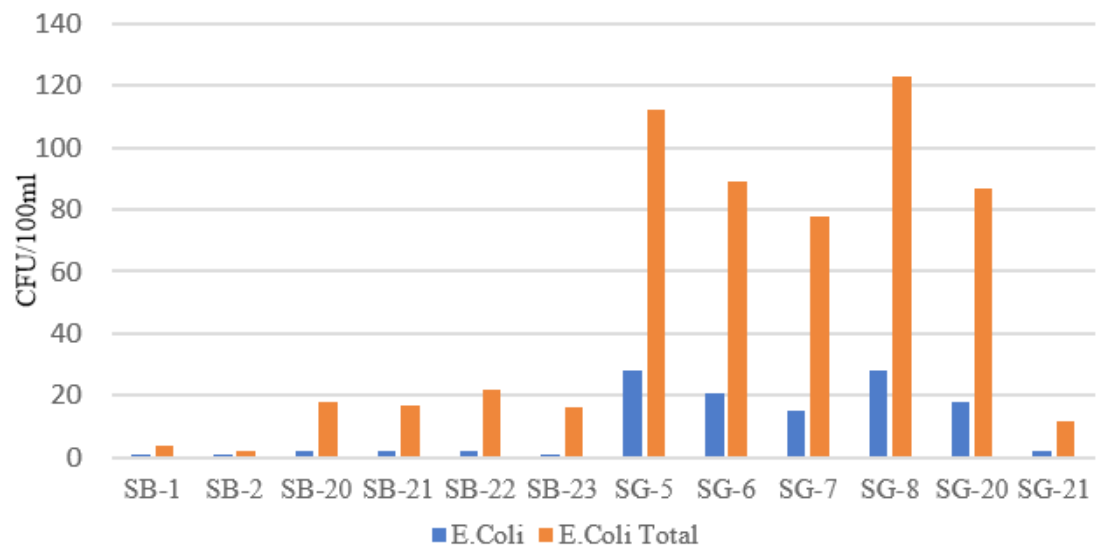

Gambar 2. Kadar E.Coli dan E.Coli total melebihi baku mutu

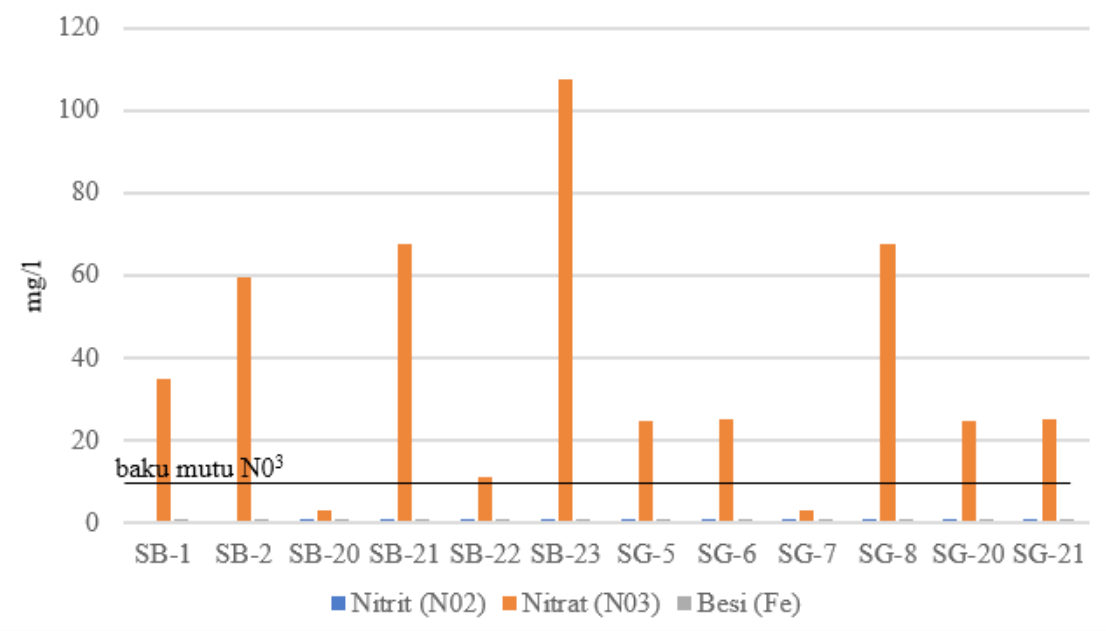

Gambar 3. Kadar $\mathrm{N}^{2}, \mathrm{~N} 0^{3}$ melebihi baku mutu dan $\mathrm{Fe}$

berbau. Parameter untuk unsur rasa seluruh sampel menunjukkan rasa sedikit asin. Rasa sedikit asin mempunyai korelasi dengan nilai daya hantar listrik (DHL) yang melebihi baku mutu dimana > $1000 \mu \mathrm{mhos} / \mathrm{cm}$ (Gambar 4). Nilai daya hantar listrik (DHL) berkorelasi dengan ion garam terlarut didalam air. Nilai yang tinggi tersebut dimungkinkan dipengaruhi oleh air laut yang bercampur dengan akuifer air tanah.

Uji untuk parameter kimia terdiri dari unsur besi $(\mathrm{Fe})$, klorida $(\mathrm{Cl})$, natrium $(\mathrm{Na})$, sulfat $\left(\mathrm{SO}_{4}\right)$, kesadahan $\left(\mathrm{CaC}^{3}\right)$, bikarbonat $\left(\mathrm{HC}^{3}\right)$, magnesium $(\mathrm{Mg})$, kalium $(\mathrm{K})$ dan kalsium $(\mathrm{Ca})$. Berdasarikan hasil uji laboratorium, nilai konsentrasi unsur besi (Fe) seluruh sampel tidak melebihi baku mutu (Gambar 3). Konsentrasi nilai khlorida $(\mathrm{Cl})$ yang melebihi batas baku mutu ditunjukkan pada sampel sumur gali yaitu SG-8, SG-20 dan SG-21. Konsentrasi khlorida $(\mathrm{Cl})$ mempunyai dampak terhadap salinitas, yang disebabkan oleh ikatan ion garam terlarut mengikat dengan ion lain. Natrium (Na) merupakan unsur senyawa yang memiliki korelasi dengan lebih besar dengan air laut dibanding dengan usur terlarut dari batu atau faktor geologi. Berdasarkan hasil uji laboratorium menunjukkan dibawah batas baku mutu dimana $>200 \mathrm{mg} / 1$ (Gambar 5).

Unsur sulfat $\left(\mathrm{SO}_{4}\right)$ mempunyai kesamaam sumber seperti natrium $(\mathrm{Na})$ yaitu dominan dari air laut selain dari batuan (faktor geologi). Berdasarkan dari hasil nilai uji laboratorium sulfat $\left(\mathrm{SO}_{4}\right)$ menunjukkan nilai dibawah baku mutu yaitu 400 $\mathrm{mg} / 1$. Konsentrasi dari unsur kesadahan $\left(\mathrm{CaC}^{3}\right)$ menunjukkan nilai melebihi baku mutu yaitu 500 $\mathrm{mg} / 1$ (Gambar 5). Sumber dari kesadahan $\left(\mathrm{CaC}^{3}\right)$ bersumber dari pelarutan kapur faktor geologi yaitu dari Formasi Paciran dan Ngratong yang tersusun atas batugamping. Unsur bikarbonat $\left(\mathrm{HCO}^{3}\right)$ dari sampel uji laboratorium menunjukkan dibawah baku mutu yaitu dibawah $500 \mathrm{mg} / 1$.

Kadar dari unsur magnesium $(\mathrm{Mg})$ sebanyak 7 sampel melebihi baku mutu yaitu $50 \mathrm{mg} / 1$, yaitu sampel SB-1, SB-2, SB-21, SB-22, SG-6, SG20 dan SG-21. Sumber magnesium (Mg) dialam bersumber dari pelarutan batuan (batu beku), dan merupakan unusr ketiga yang dominan di dari air 


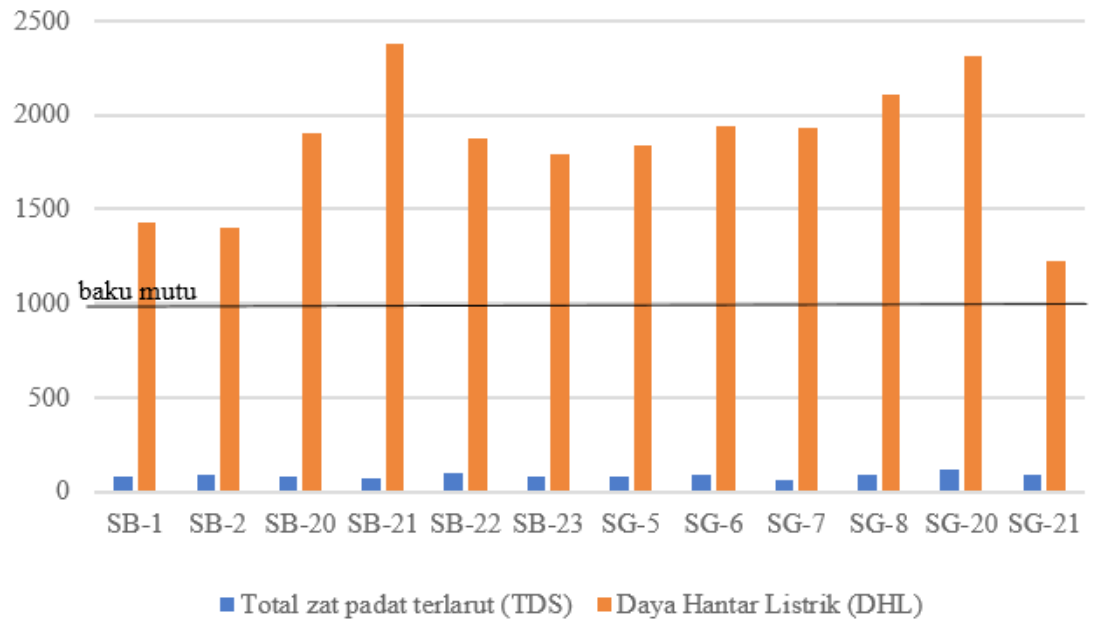

Gambar 4. Kadar TDS dan DHL

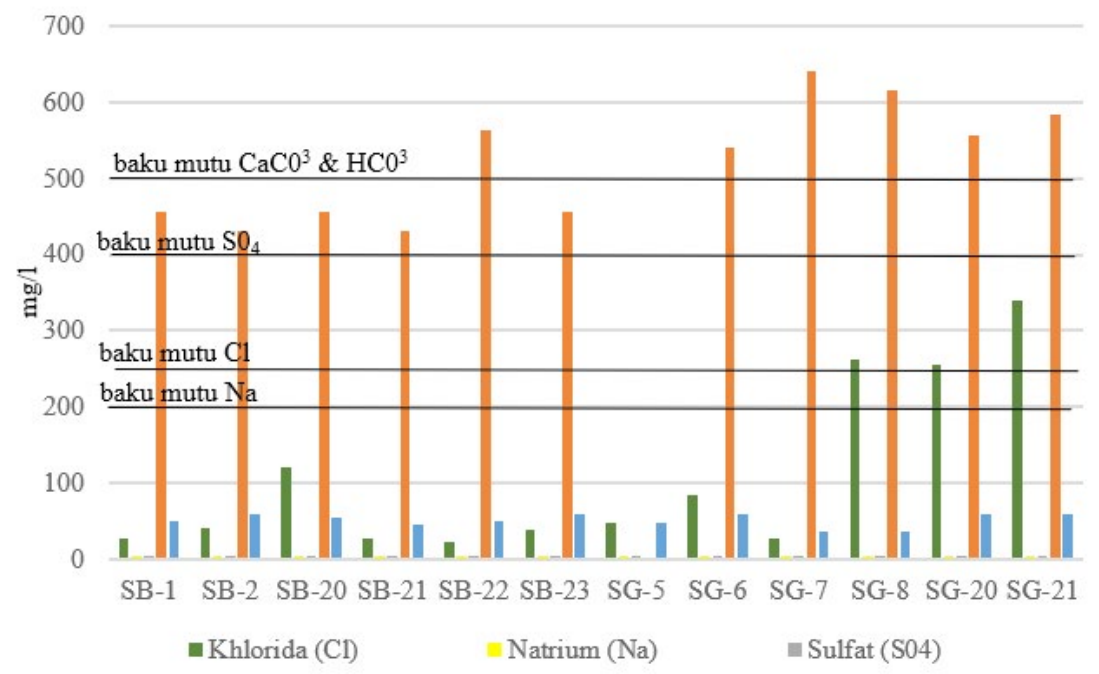

Gambar 5. Kadar $\mathrm{Cl}, \mathrm{Na}, \mathrm{SO}_{4}, \mathrm{CaCO}^{3}$, dan $\mathrm{HCO}^{3}$

laut. Seperti unsur magnesium $(\mathrm{Mg})$, unsur kalium (K) juga berumber pelarutan batu beku. Berdasarkan hasil uji laboratorium unsur kalium (K) tidak melebihi baku mutu air. Unsur yang terakhir diuji laboratorium adalah kalsium (Ca). Kalsium (Ca) bersumber dari pelarutan batuan dengan dominan kapur. Berdasarakan hasil uji laboratorium unsur kalsium (Ca) terdapat 7 sampel yang melebihi baku mutu yaitu $100 \mathrm{mg} / 1$. Sampel yang melebihi baku mutu ditunjukkan pada sampel SB-2, SB-122, SG5, SG-6, SG-8, SG-20 dan SG-2 (Gambar 6). Tingginya kadar nilai kalsium (Ca) memiliki korelasi dengan unsur kesadahan $\left(\mathrm{CaC}^{3}\right)$ dimana unsur tersebut dipengaruhi oleh batuan kapur.

Intrusi air laut menjadikan perubahan kualitas air tanah oleh penurunan tinggi muka air akibat pengambilan atau pemompaan air tanah yang berlebihan. Analisis sampel air laut menggunakan parameter perbandingan ion. Hasil analisis pengaruh intrusi airlaut terhadap airtanah di daerah pesisir diperoleh dari dua metode perbandingan ion mua- tan positif $(+)$ atau kation dan ion muatan negatif $(-)$ atau anion. Ion yang digunakan untuk perbandingan adalah ion kalsim ( $\mathrm{Ca}$ ) dengan magnesium $(\mathrm{Mg})$, dan perbandingan ion bikarbonat $\left(\mathrm{HCO}^{3}\right)$ dengan khlorida $(\mathrm{Cl})$ (Tabel 4). Nilai skala perbandingan pengaruh intrusi disajikan pada Tabel 5.

Perbandingan muatan positif (kation) yaitu perbandingan kalsium $(\mathrm{Ca})$ dan magnesium $(\mathrm{Mg})$. Satuan perbandingan ion mengunakan satuan miliequivalen per liter (meq/1). Hasil perbandingan ion kalsium $(\mathrm{Ca})$ dengan magnesium $(\mathrm{Mg})$ adalah $>1$ (Gambar 7). Kriteria perbandingan ion kalsium (Ca) dengan magnesium (Mg) $>1$ mempunyai arti bahwa sudah terpengaruhi oleh air laut. Hasil perbandingan ion nilai yang paling sedikit terpengaruh berada di titik SB-22, sedangkan nilai perbandingan tertinggi berada di titik SG-5 yang berlokasi paling dekat dengan garis pantai yang bersinggunan langsung dengan sumber intrusi yaitu air laut. Berdasarkan pengelompokan tersebut diketahui bahwa air tanah terjadinya penambahan ion mag- 


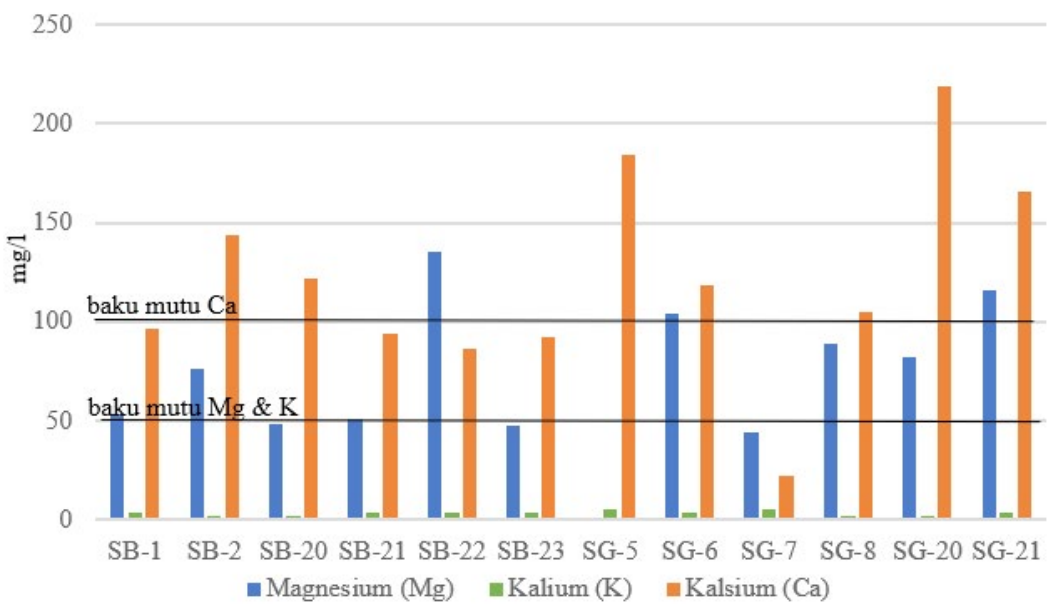

Gambar 6. Kadar Mg, K, dan Ca

Tabel 4. Parameter unsur air tanah

\begin{tabular}{|c|c|c|c|c|c|c|c|c|c|c|c|c|c|c|c|}
\hline No & Unsur & SB-1 & SB-2 & SB-20 & SB-21 & SB-22 & SB-23 & SG-5 & SG-6 & SG-7 & SG-8 & SG-20 & SG-21 & Satuan & $\begin{array}{l}\text { Baku } \\
\text { Mutu }\end{array}$ \\
\hline 1 & E.Coli & 1 & 1 & 2 & 2 & 2 & 1 & 28 & 21 & 15 & 28 & 18 & 2 & $\begin{array}{l}\text { CFU/ } \\
100 \mathrm{ml}\end{array}$ & 0 \\
\hline 2 & $\begin{array}{l}\text { E.Coli } \\
\text { Total }\end{array}$ & 4 & 2 & 18 & 17 & 22 & 16 & 112 & 89 & 78 & 123 & 87 & 12 & $\begin{array}{l}\text { CFU/ } \\
100 \mathrm{ml}\end{array}$ & 50 \\
\hline 3 & NO & 0,0009 & 0,0015 & 0,0009 & 0,0009 & 0,0009 & 0,0009 & 0,0009 & 0,0009 & 0,0009 & 0,0009 & 0,0009 & 0,0009 & $\mathrm{mg} / 1$ & 1 \\
\hline 4 & $N 0^{3}$ & 34,97 & 59,64 & 3,07 & 67,39 & 11,22 & 107,39 & 24,59 & 24,87 & 3,07 & 67,39 & 24,59 & 24,87 & $\mathrm{mg} / 1$ & 10 \\
\hline 5 & $\mathrm{Bau}$ & - & - & - & - & - & - & - & - & - & - & - & - & - & $\begin{array}{l}\text { Tidak } \\
\text { berbau }\end{array}$ \\
\hline 6 & TDS & 76,5 & 88,9 & 83,1 & 75,3 & 101 & 82 & 78,1 & 91,1 & 57,7 & 86,5 & 118,6 & 86,2 & $\mathrm{mg} / 1$ & 1000 \\
\hline 7 & Rasa & $\begin{array}{l}\text { Sedikit } \\
\text { asin }\end{array}$ & $\begin{array}{l}\text { Sedikit } \\
\text { asin }\end{array}$ & $\begin{array}{l}\text { Sedikit } \\
\text { asin }\end{array}$ & $\begin{array}{c}\text { Asin } \\
\text { sedang }\end{array}$ & $\begin{array}{l}\text { Sedikit } \\
\text { asin }\end{array}$ & $\begin{array}{l}\text { Sedikit } \\
\text { asin }\end{array}$ & $\begin{array}{l}\text { Sedikit } \\
\text { asin }\end{array}$ & $\begin{array}{l}\text { Se- } \\
\text { dikit } \\
\text { asin }\end{array}$ & $\begin{array}{l}\text { Sedikit } \\
\text { asin }\end{array}$ & $\begin{array}{c}\text { Asin } \\
\text { sedang }\end{array}$ & $\begin{array}{c}\text { Sedikit } \\
\text { asin }\end{array}$ & $\begin{array}{l}\text { Sedikit } \\
\text { asin }\end{array}$ & 1 & $\begin{array}{l}\text { Tidak } \\
\text { berasa }\end{array}$ \\
\hline 8 & DHL & 1.426 & 1.402 & 1.908 & 2.376 & 1.872 & 1.794 & 1.835 & 1.939 & 1.931 & 2.109 & 2.310 & 1.222 & $\begin{array}{c}\mu \mathrm{mhos} \\
/ \mathrm{cm}\end{array}$ & 1000 \\
\hline 9 & $\mathrm{Fe}$ & 0,001 & 0,001 & 0,070 & 0,070 & 0,070 & 0,1 & 0,001 & 0,001 & 0,001 & 0,001 & 0,1 & 0,1 & $\mathrm{mg} / 1$ & 1 \\
\hline 10 & $\mathrm{Cl}$ & 28 & 40 & 120 & 28 & 22 & 38 & 48 & 84 & 28 & 262 & 256 & 340 & $\mathrm{mg} / 1$ & 250 \\
\hline 11 & $\mathrm{SO}_{4}$ & 0,60 & 0,80 & 0,70 & 0,90 & 0,08 & 0,09 & 0,90 & 0,90 & 0,03 & 0,06 & 0,09 & 0,08 & $\mathrm{mg} / 1$ & 400 \\
\hline 12 & $\mathrm{CaCO}_{3}$ & 456 & 432 & 456 & 432 & 564 & 456 & 440 & 540 & 640 & 616 & 556 & 584 & $\mathrm{mg} / 1$ & 500 \\
\hline 13 & $\mathrm{pH}$ & 7,26 & 7,32 & 7,45 & 7,26 & 7,74 & 7,28 & 7,44 & 7,49 & 7,49 & 7,36 & 7,53 & 7,66 & $\mathrm{mg} / 1$ & $\begin{array}{c}6,5- \\
8,5\end{array}$ \\
\hline 14 & $\mathrm{Na}$ & 2,89 & 3,23 & 1,80 & 2,17 & 2,53 & 2,95 & 2,02 & 1,57 & 4,17 & 3,86 & 3,20 & 2,18 & $\mathrm{mg} / 1$ & 200 \\
\hline 15 & $K$ & 3,01 & 1,07 & 1,30 & 3,11 & 3,33 & 3,33 & 4,81 & 3,46 & 4,77 & 1,19 & 1,72 & 3,20 & $\mathrm{mg} / 1$ & 50 \\
\hline 16 & $\mathrm{HCO}^{3}$ & 51 & 59 & 54,30 & 45,80 & 51 & 58 & 48 & 58 & 36,40 & 36,40 & 58 & 58 & $\mathrm{mg} / 1$ & 500 \\
\hline 17 & $\mathrm{Ca}$ & 96 & 144 & 122 & 94 & 86 & 92 & 184 & 118 & 22 & 105 & 219 & 166 & $\mathrm{mg} / 1$ & 100 \\
\hline \multirow{2}{*}{18} & $M g$ & 53 & 76 & 48 & 51 & 135 & 47 & 20 & 104 & 44 & 89 & 82 & 116 & $\mathrm{mg} / 1$ & 50 \\
\hline & $\begin{array}{l}\text { CBE } \\
(\%)\end{array}$ & 2,10 & 4,30 & 0,70 & 3,70 & 1,90 & 0,10 & 7,60 & 7,10 & 1,00 & 3,40 & 7,70 & 4,90 & & \\
\hline
\end{tabular}

Tabel 5. Sebaran nilai perbandingan ion tehadap air tanah

\begin{tabular}{crrrrrrrrrrrrr}
\hline No & Unsur (mg/l) & SB-1 & SB-2 & SB-20 & SB-21 & SB-22 & SB-23 & SG-5 & SG-6 & SG-7 & SG-8 & SG-20 & SG-21 \\
\hline 1 & Magnesium (Mg) & 53 & 76 & 48 & 51 & 135 & 47 & 20 & 104 & 44 & 89 & 82 & 116 \\
2 & Kalsium (Ca) & 96 & 144 & 122 & 94 & 86 & 92 & 184 & 118 & 22 & 105 & 219 & 166 \\
3 & Ca/Mg & 1,81 & 1,89 & 2,54 & 1,84 & 0,64 & 1,96 & 9,20 & 1,13 & 0,50 & 1,18 & 2,67 & 1,43 \\
4 & Khlorida (Cl) & 28 & 40 & 120 & 28 & 22 & 38 & 48 & 84 & 28 & 262 & 256 & 340 \\
5 & Bikarbonat (HC0 $\left.{ }^{3}\right)$ & 51 & 59 & 54.3 & 45.8 & 51 & 58 & 48 & 58 & 36.4 & 36.4 & 58 & 58 \\
$\mathbf{6}$ & CL/HC0 & 0,55 & 0,68 & 2,21 & 0,61 & 0,43 & 0,66 & 1,00 & 1,45 & 0,77 & 7,20 & 4,41 & 5,86 \\
\hline
\end{tabular}


nesium $(\mathrm{Mg})$ dari air laut. Sifat jumlah penambahan magnesium $(\mathrm{Mg})$ dengan kaslium $(\mathrm{Ca})$ relatif stabil menunjukkan pengaruh intrusi oleh air laut. Pengaruh intrusi air laut akan menimbulkan pergeseran ion kaslium $(\mathrm{Ca})$ dengan magnesium $(\mathrm{Mg})$ oleh kalium (K) dan natrium $(\mathrm{Na})$.

Analisis pengaruh intrusi dapat diketahui juga dari perbandingan ion ion muatan negatif (-) atau anion. Perbandingan ion muatan negatif (-) atau anion mengunakan komposisi klorida $(\mathrm{Cl})$ dengan bikarbonat $\left(\mathrm{HCO}^{3}\right)$. Hasil dari perbandingan ion negtif (-) adalah skala $>0,5$ batas tepengaruh intrusi air laut (Gambar 8). Nilai terkecil berada di titik SB-22, sama seperti pada perbandingan ion kalsium $(\mathrm{Ca})$ dan magnesium $(\mathrm{Mg})$. Nilai skala $>0,5$ dalam perbandingan ion muatan negatif menunjukan bahwa semua sampel air tanah terpengaruh oleh intrusi air laut. Tingkat pengaruh intrusi kecil terdapat pada sampel SB-1, SB-2, SB-21, SB-23, SG-5, dan SG-7. Intrusi tingkat pengaruh sedang ditunjukkan pada sampel SG-6 dan SB-20.
Tingkat intrusi pengaruh cukup besar ditunjukkan pada sampel SG-20 dan SG-21 sedangkan sampel dengan tingkat pengaruh terbesar ditunjukkan pada sampel SG-8 yang berlokasi dekat dengan garis pantai.

Sampel SB-23, SG-5, SG-7, SG-6, SB-20. SG-20 dan SG-21 menunjukkan perbandingan nilai klorida $(\mathrm{Cl})$ yang relatif lebih tinggi mengindikasikan memiliki kemiripan mineral ion garam laut. Sifat ion negatif klorida $(\mathrm{Cl})$ sangat dipengaruhi oleh air laut karena merupakan penyusun mineral di perairan laut. sedangkan dengan bikarbonat $\left(\mathrm{HCO}^{3}\right)$ adalah reaksi dari pelarutan batuan yang dilalui oleh aliran airtanah. Perbandingan bikarbonat $\left(\mathrm{HCO}^{3}\right)$ dan klorida $(\mathrm{Cl})$ dengan nilai yang meningkat atau tinggi pada sampel SG-8 mengindikasikan terjadinya pergerakan air tanah terpengaruh oleh air laut dan bila nilai klorida $(\mathrm{Cl})$ meningkat tajam (sangat tinggi) menunjukkan laju intrusi yang semakin besar.

Nilai daya hantar listrik (DHL) memiliki ko-

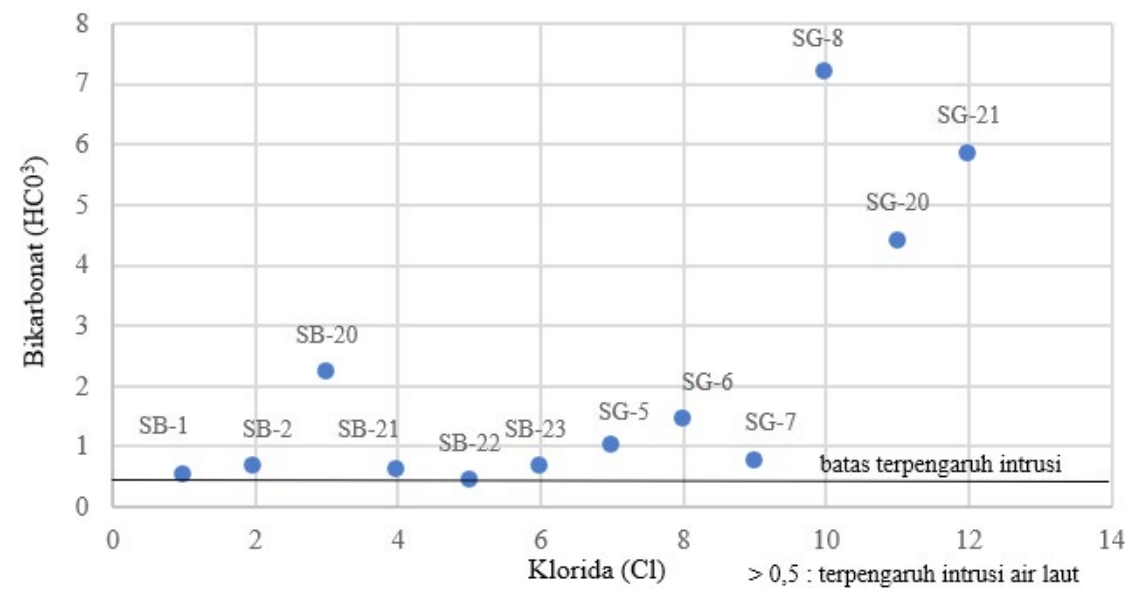

Gambar 8. Distribusi perbandingan ion $\mathrm{HC}^{3}$ dan $\mathrm{Cl}$ terhadap air tanah

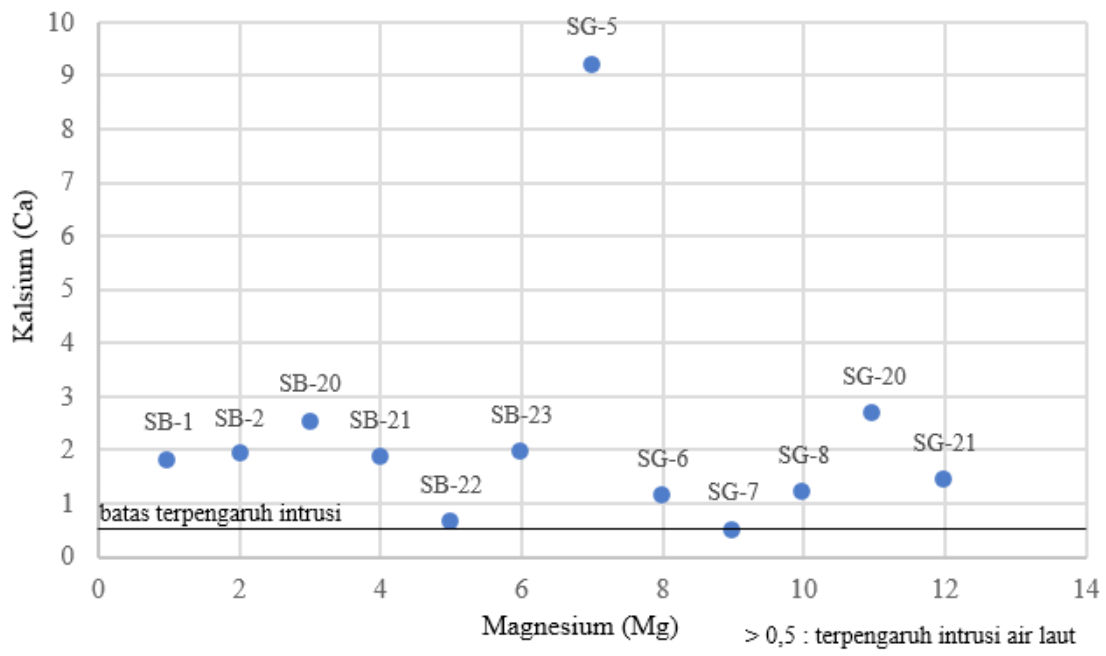

Gambar 7. Distribusi perbandingan ion $\mathrm{Ca}$ dan $\mathrm{Mg}$ terhadap air tanah 


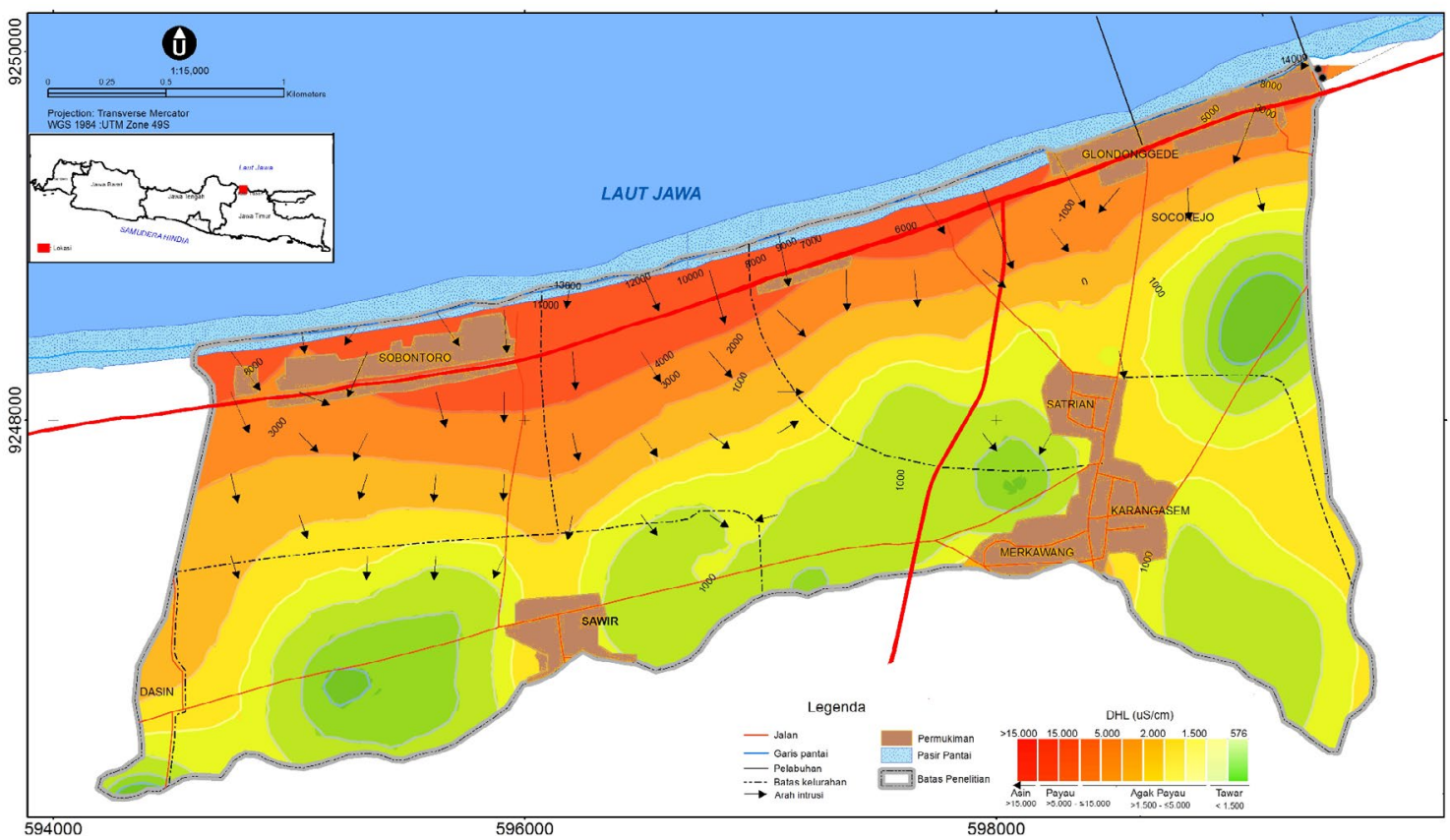

Gambar 9. Distribusi nilai DHL dan arah pengaruh intrusi

relasi dengan salinitas yang dipengaruhi oleh kandungan ion garam terlarut. Garam terlarut dipengaruhi oleh jarak dari sumber kontaminasi yaitu air laut. Hal tersebut dipengaruhi juga oleh unsur yang bersumber domain dari laut yaitu kalsium $(\mathrm{Ca})$ dan klorida $(\mathrm{Cl})$. Berdasarkan hasil laboratorium dari unsur nilai daya hantar listrik dapat mengambarkan secara keruangan (spasial) terpengaruh air laut.

Berdasarkan nilai daya hantar listrik (DHL) seluruh sampel mendapat pengaruh air asin kecil hingga sedang Berdasarkan nilai daya hantar listrik Desa Sobontoro, Glondonggede dan Socorejo mendapat pengaruh terbesar dari intrusi air laut disebabkan oleh jarak yang paling dekat dengan garis pantai. Sedangkan Desa Sawir, Satrian, Karangasem dan Merkawang terpengaruh intrusi air laut kecil. Arah distribusi nilai daya hantar listrik (DHL) pengaruh asin membentuk arah ke permukiman, yang mengindikasikan bahwa air asin tertarik hingga ke akuifer tawar yang berada di sekitar permukiman. Distribusi nilai daya hantar listrik (DHL) disajikan pada Gambar 9.

\section{KESIMPULAN}

Berdasarkan penelitian dapat disimpulkan bahwa unsur yang melebihi baku mutu antara lain ecoli yang bersumber dari limbah rumah tangga (domestik), nitrat ( $\mathrm{N}^{3}$ )yang bersumber dari pupuk pertanian, daya hantar litrik (DHL) bersumber dari ion garam terlarut dan kesadahan $\left(\mathrm{CaCO}^{3}\right)$ yang bersumber dari batuan gamping. Sedangkan metode untuk mengetahui dampak intrusi air laut ada- lah dengan perbandingan ion mayor yaitu magnesium $(\mathrm{Mg})$ dan kalsium $(\mathrm{Ca})$, dan klorida $(\mathrm{Cl})$ dan bikarbonat $\left(\mathrm{HC}^{3}\right)$ Hasil penelitian menunjukkan 11 dari 12 sampel atau 91\% terpengaruh intrusi air laut.

\section{DAFTAR PUSTAKA}

Aris, A.Z.; Pravenaa, S.M. dan Isa, N.M., 2013. Groundwater composition and geochemical controls in small tropical island of Malaysia : Comparative study dalam Wetzelhuetter, C. 2013. Groundwater in The Coastal Zone of Asia-Pasific. Dordrecht: Springer.

Febriarta E., Prabawa B. A., Rosaji F.S.C., 2018. Sumber Daya Air di Pulau Pelapis Kepuluan karimata, Kabupaten Kayong Utara, Kalimantan Barat. Prosiding Seminar nasional Ke- Pengelolaan Pesisir dan Daerah Alira Sungai.4.181-186. doi 10.17605/osf.io/v6nx8.

Fetter, C.W., 2014. Applied Hydrogeology Fourth Edition. Pearson New Interbational Education: England.

Hounsinou S.P., 2020.Assessment of potential seawater intrusion in a coastal aquifer system at Abomey - Calavi, Benin.Heliyon.6(2).doi.org/10.1016/j.heliyon.2020. e03173

Mishra, P., Panda, U.S., Pradhan U., Kumar,C.S., Mehmuna B., and Ishwarya, 2015. Coastal Water Quality Monotoring And Modeling Off Chennai City. Procedia Enginerring.116.2015.955-962.

Purnama S., 2010. Hidrologi Airtanah. Yogyakarta: Penerbit Kanisius

Singhal, B.B.S. and Gupta, R.P., 2010. Applied Hydogeology of Fracture Rock. Springer Dordrecht Heidelberg London: Springer.

Suhartono E., Purwanto P.,dan Suripin S., 2015. Seawater Intrusion Modeling On Groundwater Confined Aquifer In Semarang. Procedia Environmental Sciences 23: 110115.

Suherman D., 2007. Mata Air Sebagai Sumber Air Bersih di Pulau-Pulau Kecil, Maluku Tenggara. Dalam Hehanusa, P.E. dan Bhakti, H. (eds) 2005. Sumber Daya Air di 
Pulau Kecil. Bandung: Lipi Press.

Todd, D.K. and Mays, L.W., 2005, Groundwater Hydrology 3rd Edition, Denver: John Wiley \& Sons, Inc.

Widada S., Rochaddi B.,Suryono C., dan Irwani I., 2018. Intrusi Air Laut Berdasarkan Resistiviti dan Hidrokimia di Pesisir Tugu Kota Semarang Indonesia. Jurnal Kelautan Tropis.21(2). 75-80. doi.org/10.14710/jkt. v21i2.3610

Younger, P.L. 2007. Groundwater In The Environment. Oxford UK: Blackwwell Publishing. 